\title{
Spark Plasma Sintering of Boron Carbide Ceramics Using Metallic Silicon in Square Cross Section
}

\author{
M. Cengiz*, F. C. SAhin \\ Istanbul Technical University, Metallurgical and Materials \\ Engineering Department, 34469 Maslak, Istanbul, Turkey
}

\begin{abstract}
$\mathrm{B}_{4} \mathrm{C}$ ceramics were fabricated by spark plasma sintering (SPS) technique with 5 vol.\% silicon as sintering additive. Optimization of SPS method production parameters for $\mathrm{B}_{4} \mathrm{C}$ ceramics having geometries $50 \times 50 \times 5 \mathrm{~mm}$, square cross section will be performed. The sintering process was carried out at different temperatures by applying $40 \mathrm{MPa}$ of pressure under vacuum atmosphere. The effect of silicon additive, sintering temperature and different soaking times on density, vickers hardness, fracture toughness and microstructure were examined. The mechanical properties of the $\mathrm{B}_{4} \mathrm{C}$ ceramics having silicon as additive were compared with the results of monolithic $\mathrm{B}_{4} \mathrm{C}$. The hardness and fracture toughness of the samples were evaluated by the vickers indentation technique. Microstructures of spark plasma sintered $\mathrm{B}_{4} \mathrm{C}$ samples with different parameters in square cross section were characterized by using SEM technique.
\end{abstract}

DOI: $10.12693 /$ APhysPolA.127.1370

PACS: 81.20.Ev

\section{Introduction}

Ceramics are attractive materials for ballistic protection applications due to their high hardness, high flexural strength and low density when compared to metals. Among those materials, boron carbide $\left(\mathrm{B}_{4} \mathrm{C}\right)$ is evaluated as an ideal material for ballistic protection applications, especially for light armor, since it is the third hardest material after diamond and cubic boron nitride and it exhibits higher hardness and lower density when compared to other ceramics $[1,2]$.

In recent years, Spark Plasma Sintering (SPS) technique has been used widely for manufacturing boron carbide and related boron carbide ceramics because of the positive effects on microstructure since it prevents grain coarsening. With applying external electric field, SPS enhances densification and the sintering process is completed at lower temperatures in short times without grain growth compared to the traditional methods (pressureless sintering, hot pressing and hot isostatic pressing). These unique properties make SPS a preferable candidate for producing boron carbide ceramics [3-5].

In one of the studies Frage et al. stated that presence of $\mathrm{Si}$ increases the wetting properties and decreases the sintering temperature 30 to $60{ }^{\circ} \mathrm{C}$ and in more Si additions it is assumed that the sintering temperature could be decreased even further [6]. Ye et al. mixed $0 \%$ to $10 \% \mathrm{Si}$ powder in weight with $\mathrm{B}_{4} \mathrm{C}$ and SPS'ed the powders in graphite dies having $20 \mathrm{~mm}$ inner diameter after applying $50 \mathrm{MPa}$ pressure at $1800{ }^{\circ} \mathrm{C}$ with $100{ }^{\circ} \mathrm{C} / \mathrm{min}$ heating rate for 5 minutes. 4,8 and $10 \% \mathrm{Si}$ is added to the monolithic $\mathrm{B}_{4} \mathrm{C}$ and $\mathrm{Si}$ is observed to make liq-

* corresponding author; e-mail: cinar@itu.edu.tr uid phase sintering and assisted in increasing the relative density values from $99.0 \%$ to $99.93 \%$ [7].

\section{Experimental}

Commercial HS grade $\mathrm{B}_{4} \mathrm{C}$ powders from German H.C. Starck Company, with an average particle size of $1.78 \mu \mathrm{m}$ and metallic Si, 324 mesh powder from Alpha Aeser Company were used in the present study. In the experiments that silicon was used as $5 \%$ in volume, suspensions were prepared by mixing $\mathrm{B}_{4} \mathrm{C}$ and $\mathrm{Si}$ powder with $\mathrm{SiC}$ balls in Merck quality ethanol medium by ball milling for 24 hours. The slurry was then dried and screened from 100 micron openings. After screening, the dry powder was loaded in a graphite die for conducting in SPS.

The samples were sintered by using the SPS apparatus (SPS-7.40MK-VII, SPS Syntex Inc.). After applying initial pressure as $10 \mathrm{MPa}, 100{ }^{\circ} \mathrm{C} / \mathrm{min}$ heating rate from room temperature to sintering temperature was used under vacuum atmosphere. The temperature of the die was measured by an optical pyrometer. Samples were subjected to different soaking times at different temperatures applying different pressure values. Whole process was carried out in vacuum atmosphere and shrinkage, displacement rate, heating current, and voltage for every $5 \mathrm{~s}$ was recorded. At the end of the process, sintered compacts were obtained. After the sintering process, Archimedes method was used to determine the final relative densities of the compacts. Specimens, polished with a diamond paste having particle size of $1 \mu \mathrm{m}$ were subjected to the hardness and fracture toughness tests at room temperature and were evaluated by the Vickers indentation technique at a load of $1 \mathrm{~kg}$. The micrographs of all sample surfaces were observed by scanning electron microscopy (SEM; Model JSM 7000F, JEOL, Tokyo, Japan). 


\section{Results and discussion}

Starting powders and spark plasma sintering conditions along with the relative density values of the sintered ceramics are given in Table. All of the samples are produced in square cross section under vacuum atmosphere and aimed to have $5 \mathrm{~mm}$ thickness after sintering and the powders are heated with $100{ }^{\circ} \mathrm{C} /$ min heating rate and sintered for different soaking times. The sintering temperatures are defined by checking the completion of the shrinkage amounts. Maximum relative density values are achieved at the temperatures where the shrinkage is completed and the samples are kept constant at that temperature for 4 minutes.

The first sample in Table is monolithic HS-grade boron carbide that has been sintered at $1530{ }^{\circ} \mathrm{C}$ applying $40 \mathrm{MPa}$ pressure having soaking time of $5 \mathrm{~min}$. Sintering temperatures $\left(1300,1400,1500{ }^{\circ} \mathrm{C}\right)$; applied pressure (40 and $60 \mathrm{MPa}$ ) and soaking times ( 0 and 4 minutes) are used as spark plasma sintering variables and investigated under the scope of this study. The highest relative density values are achieved from the compacts spark plasma sintered at $1500{ }^{\circ} \mathrm{C}$ by applying $60 \mathrm{MPa}$ for $4 \mathrm{~min}$. The most significant effect of sintering parameters on relative density is observed to be sintering temperatures. For instance; the compacts spark plasma sintered at $1300{ }^{\circ} \mathrm{C}$ under $40 \mathrm{MPa}$ for 0 minute has $85.4 \%$ relative density whereas other compacts have $89.9 \%$ and $92.6 \%$ relative density for $1400{ }^{\circ} \mathrm{C}, 1500{ }^{\circ} \mathrm{C}$ respectively where applied pressure, soaking time, additive amount and heating rate are kept constant. As soaking time increased from 0 to 4 minutes and applied pressure increased from 40 to $60 \mathrm{GPa}$, relative density values increased. The sample which gave the highest relative density value as $99.2 \%$ and highest hardness value as $31.4 \pm 0.1$ within $5 \% \mathrm{Si}$ added samples is the compact that is sintered at $1500{ }^{\circ} \mathrm{C}$ under $60 \mathrm{MPa}$ with 4 minutes soaking time.

Hardness and fracture toughness values of the sintered ceramics are also given in Table. The highest hardness $32.6 \pm 0.1 \mathrm{GPa}$ is obtained from the monolithic boron carbide sample sintered at $1550{ }^{\circ} \mathrm{C}$ under $40 \mathrm{MPa}$ for 5 minutes. The fracture toughness values of the samples that have very high amount of pores and relative density values below $95 \%$ having $5 \%$ metallic silicon as additive, couldn't be measured due to the lack of crack formation and detection of the crack. Adding 5\% metallic Si in boron carbide ceramics decreased the hardness value from $32.6 \pm 0.1$ to $31.4 \pm 0.1$; however, as the compacts get denser, the hardness values increased significantly.

XRD micrographs of initial powder mixture, compacts sintered at $1300{ }^{\circ} \mathrm{C}, 1400{ }^{\circ} \mathrm{C}$ and $1500{ }^{\circ} \mathrm{C}$ at $40 \mathrm{MPa}$, 0 minutes and 4 minutes; compacts sintered at $1300{ }^{\circ} \mathrm{C}$, $1400{ }^{\circ} \mathrm{C}$ and $1500{ }^{\circ} \mathrm{C}$ at $60 \mathrm{MPa}$ for 4 minutes is given in Fig. 1. In the first XRD patterns which belong to the initial powder mixture; only $\mathrm{B}_{4} \mathrm{C}$ and $\mathrm{Si}$ phases are observed. Figure $1 \mathrm{~b}$ belongs to the XRD patterns of the compacts sintered at $1300{ }^{\circ} \mathrm{C}$ at $40 \mathrm{MPa}$ for 0 minutes that consists of $\mathrm{B}_{4} \mathrm{C}, \mathrm{B}_{2} \mathrm{O}_{3}, \mathrm{SiC}, \mathrm{C}$ and $\mathrm{SiO}_{2}$ phases. As the temperature, soaking time and applied pressure
Relative density, hardness and fracture toughness values of differently processed spark plasma sintered HS-grade boron carbide ceramics.

\begin{tabular}{c|c|c|c|c}
\hline \hline $\begin{array}{c}\text { Starting } \\
\text { powder }\end{array}$ & SPS process & $\begin{array}{c}\text { Rel. } \\
\text { density } \\
{[\%]}\end{array}$ & $\begin{array}{c}\text { Hardness } \\
{[\mathrm{GPa}]}\end{array}$ & $\begin{array}{c}\text { Fracture } \\
\text { toughness } \\
{\left[\mathrm{MPa} \cdot \mathrm{m}^{1 / 2}\right]}\end{array}$ \\
\hline $\mathrm{B}_{4} \mathrm{C}^{* *}$ & $1550{ }^{\circ} \mathrm{C}, 40 \mathrm{MPa}, 5 \mathrm{~min}$ & 98.9 & $32.6 \pm 0.1$ & $3.0 \pm 0.1$ \\
$\mathrm{~B}_{4} \mathrm{C}^{*}$ & $1300{ }^{\circ} \mathrm{C}, 40 \mathrm{MPa}, 0 \mathrm{~min}$ & 85.4 & $3.8 \pm 0.1$ & porous \\
$\mathrm{B}_{4} \mathrm{C}^{*}$ & $1400{ }^{\circ} \mathrm{C}, 40 \mathrm{MPa}, 0 \mathrm{~min}$ & 89.9 & $5.4 \pm 0.1$ & porous \\
$\mathrm{B}_{4} \mathrm{C}^{*}$ & $1500{ }^{\circ} \mathrm{C}, 40 \mathrm{MPa}, 0 \mathrm{~min}$ & 92.6 & $23.9 \pm 0.1$ & porous \\
$\mathrm{B}_{4} \mathrm{C}^{*}$ & $1300{ }^{\circ} \mathrm{C}, 40 \mathrm{MPa}, 4 \mathrm{~min}$ & 88.9 & $4.9 \pm 0.1$ & porous \\
$\mathrm{B}_{4} \mathrm{C}^{*}$ & $1400{ }^{\circ} \mathrm{C}, 40 \mathrm{MPa}, 4 \mathrm{~min}$ & 89.3 & $7.4 \pm 0.1$ & porous \\
$\mathrm{B}_{4} \mathrm{C}^{*}$ & $1500{ }^{\circ} \mathrm{C}, 40 \mathrm{MPa}, 4 \mathrm{~min}$ & 95.5 & $24.0 \pm 0.1$ & $5.9 \pm 0.1$ \\
$\mathrm{~B}_{4} \mathrm{C}^{*}$ & $1300{ }^{\circ} \mathrm{C}, 60 \mathrm{MPa}, 4 \mathrm{~min}$ & 92.3 & $5.8 \pm 0.1$ & porous \\
$\mathrm{B}_{4} \mathrm{C}^{*}$ & $1400{ }^{\circ} \mathrm{C}, 60 \mathrm{MPa}, 4 \mathrm{~min}$ & 91.8 & $9.1 \pm 0.1$ & porous \\
$\mathrm{B}_{4} \mathrm{C}^{*}$ & $1500{ }^{\circ} \mathrm{C}, 60 \mathrm{MPa}, 4 \mathrm{~min}$ & 99.2 & $31.4 \pm 0.1$ & $4.7 \pm 0.1$ \\
\hline
\end{tabular}

${ }^{*} \mathrm{HS}$ Grade $+5 \% \mathrm{Si},{ }^{* *} \mathrm{HS}$ Grade.

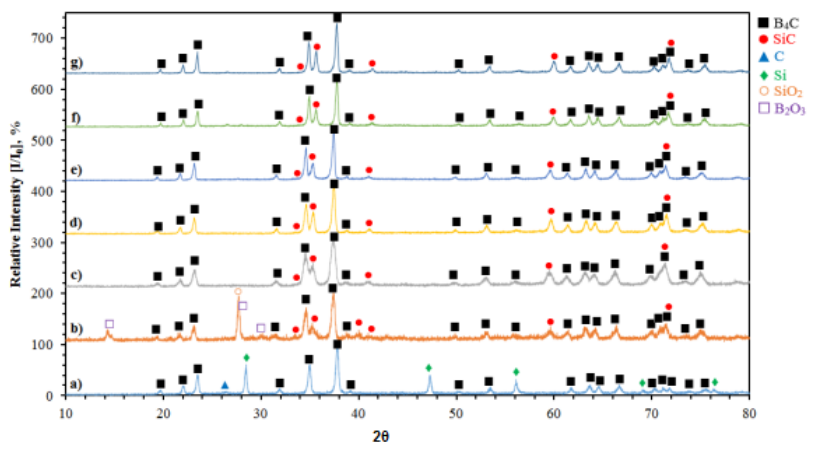

Fig. 1. XRD micrographs of (a) initial powder mixture; compacts sintered at (b) $1300{ }^{\circ} \mathrm{C}$ under $40 \mathrm{MPa}$ for 0 min. (c) $1400{ }^{\circ} \mathrm{C}$ under $40 \mathrm{MPa}$ for $0 \mathrm{~min}$. (d) $1500{ }^{\circ} \mathrm{C}$ under $40 \mathrm{MPa}$ for $0 \mathrm{~min}$. (e) $1300{ }^{\circ} \mathrm{C}$ under $40 \mathrm{MPa}$ for $4 \mathrm{~min}$. (f) $1300{ }^{\circ} \mathrm{C}$ under $60 \mathrm{MPa}$ for $4 \mathrm{~min}$. (g) $1500{ }^{\circ} \mathrm{C}$ under $60 \mathrm{MPa}$ for $4 \mathrm{~min}$.

increased, oxide phases and carbon disappeared due to kinetic factors.

Fracture surface SEM images are given in Fig. 2, which provided the effect of sintering temperature, soaking time and applied pressure. Difference of the grain sizes of sintered ceramics are due to the sintering conditions. Figure 2a belongs to the compacts sintered at $1300{ }^{\circ} \mathrm{C}$ at $40 \mathrm{MPa}$ for $0 \mathrm{~min}$ that have $85.4 \%$ relative density. While only increasing the sintering temperature from $1300{ }^{\circ} \mathrm{C}$ to $1500{ }^{\circ} \mathrm{C}$; average grain sizes are observed to increase from 1-2 $\mu \mathrm{m}$ to $5-6 \mu \mathrm{m}$. It is also observed that the average grain size increased as the applied pressure increased from $40 \mathrm{MPa}$ to $60 \mathrm{MPa}$ at $1300{ }^{\circ} \mathrm{C}$ with 4 minutes soaking times. Samples sintered at $1500{ }^{\circ} \mathrm{C}$ under $40 \mathrm{MPa}$ for 0 minute have relatively the coarsest average grains and samples sintered at $1500{ }^{\circ} \mathrm{C}$ under $60 \mathrm{MPa}$ for $4 \mathrm{~min}$ is observed to have the least amount of pores.

\section{Conclusion}

In this study, effects of sintering parameters such as sintering temperature, soaking time and applied pressure 


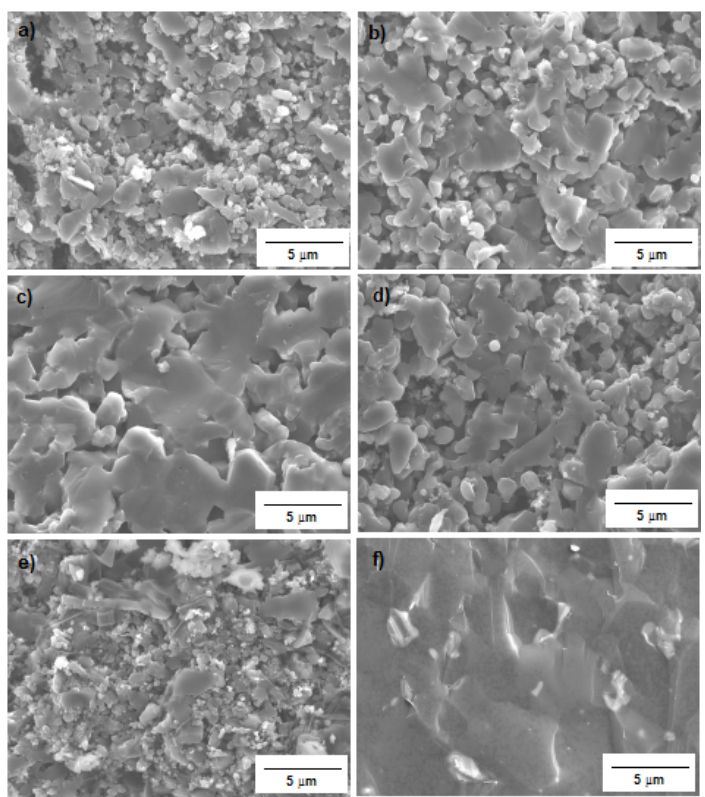

Fig. 2. SEM micrographs of compacts sintered at (a) $1300{ }^{\circ} \mathrm{C}$ at $40 \mathrm{MPa}$ for $0 \mathrm{~min}(\mathrm{~b}) 1400{ }^{\circ} \mathrm{C}$ at $40 \mathrm{MPa}$ for 0 min. (c) $1500{ }^{\circ} \mathrm{C}$ at $40 \mathrm{MPa}$ for $0 \mathrm{~min}$ (d) $1300{ }^{\circ} \mathrm{C}$ at $40 \mathrm{MPa}$ for $4 \mathrm{~min}$ (e) $1300{ }^{\circ} \mathrm{C}$ at $60 \mathrm{MPa}$ for $4 \mathrm{~min}$. (f) $1500{ }^{\circ} \mathrm{C}$ at $60 \mathrm{MPa}$ for $4 \mathrm{~min}$.

is investigated along with effect of $5 \%$ metallic silicon addition. In this study $\mathrm{B}_{4} \mathrm{C}$ ceramics are produced by using Spark Plasma Sintering (SPS) method and physical and mechanical characterization of those ceramics are performed. Optimization of SPS method production parameters for $\mathrm{B}_{4} \mathrm{C}$ ceramics having $50 \times 50 \times 5 \mathrm{~mm}$ dimensions and 5 volumetric $\% \mathrm{Si}$ added to $\mathrm{B}_{4} \mathrm{C}$ will be performed.

Cengiz et al. stated that HS-grade boron carbide ceramics processed under vacuum atmosphere with density values up to $98.9 \%$ was attained by spark plasma sintering technique from $8 \mathrm{~mm}$ thick samples having $50 \times 50 \mathrm{~mm}$ cross section [8]. For further investigations spark plasma sintering conditions can be changed such as increasing the temperature, heating rate and metallic Si amount. Highest hardness values are determined in monolithic HS-grade boron carbide samples. Vickers hardness of the samples ranged between 3.8 to $32.6 \pm 0.1 \mathrm{GPa}$ and fracture toughness values were measured between $3.0 \pm 0.1 \mathrm{MPa} \mathrm{m}^{1 / 2}$ to $5.9 \pm 0.1 \mathrm{MPa} \mathrm{m}^{1 / 2}$. $\mathrm{S}$. Hayun et al. measured the fracture toughness values from the Palmqvist crack system equations to be between 3.9 and $4.9 \mathrm{MPa} \mathrm{m}^{1 / 2}[9]$. In addition, the pure HS graded ceramics required higher temperature in order to achieve higher densities. Fracture toughness from the porous samples couldn't be achieved due to lack of crack formation by the indentation method. However, it is observed that with addition of $5 \%$ metallic $\mathrm{Si}$, fracture toughness value is increased as well as the relative densities.

It should be bared in mind that the sintering temperature is defined by optical pyrometer from the surface of the graphite die and minor changes in the die geometries, dimensions and die wall thickness affect the spark plasma sintering process parameters drastically [10].

\section{Acknowledgment}

The authors express their gratitude to the Scientific and Technological Research Council of TurkeyTUBITAK for the financial support by the projection 213M163, and to Istanbul Technical University Department of Scientific Research Projects-BAP for their financial support. And authors also thank Prof. Dr. Onuralp Yucel and Prof. Dr. Gultekin Goller for their support and contribution.

\section{References}

[1] F. The'venot, Journal of the European Ceramic Society 6, 205 (1990).

[2] H. Lee, R.F. Speyer, Journal of the American Ceramic Society 86, 1468 (2003).

[3] B. Yeşilkaya, G. ve Ibişoğlu in: Bor Karbŭr Ŏn Fiz-

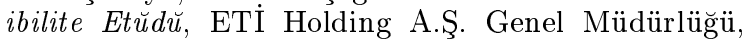
Ankara 2003.

[4] M. Omori, Institute for Materials Research, Tohoku University, Sendai 980-8577, Japan 287, (2000).

[5] H.O. Pierson in: Handbook Of Refractory Carbides And Nitrides Properties, Characteristics, Processing and Applications, Consultant and Sandia National Laboratories. New Mexico 1996.

[6] N. Frage, N.L. Levin, M. Frumin, Gelbstein, M.P. Daniel, Journal of Materials Processing Technology 143, 486 (2003).

[7] F. Ye, Z. Hou, H. Zhang, L. Liu, Journal of American Ceramic Society, 2956 (2010).

[8] M. Cengiz, B. Yavas, Y. Celik, G. Goller, O. Yucel, F.C. Sahin, Acta Physica Polonica A 125, 260 (2014).

[9] S. Hayun, S. Kalabukhov, V. Ezersky, M.P. Dariel, N. Frage, Ceramics International 36, 451 (2010).

[10] R.S. Dobedoe, G.D. West, M.H. Lewis, Advances in Applied Ceramics 104, 110 (2005). 